\title{
Review
}

\section{An Update on Nutrients and Blood Pressure}

\section{Summary of INTERMAP Study Findings}

\author{
Queenie Chan ${ }^{1,2}$, Jeremiah Stamler ${ }^{3}$, Linda M. Oude Griep ${ }^{1,2}$, Martha L. Daviglus ${ }^{3,4}$, Linda Van Horn ${ }^{3}$ and \\ Paul Elliott ${ }^{1,2}$
}

\footnotetext{
${ }^{1}$ Department of Epidemiology and Biostatistics, School of Public Health, Imperial College London, London, UK

${ }^{2}$ MRC-PHE Centre for Environment and Health, School of Public Health, Imperial College London, London, UK

${ }^{3}$ Department of Preventive Medicine, Feinberg School of Medicine, Northwestern University, Chicago, IL, USA

${ }^{4}$ Institute for Minority Health Research, University of Chicago, IL, USA
}

Adverse blood pressure (BP) is a major independent risk factor for epidemic cardiovascular diseases affecting almost one-quarter of the adult population worldwide. Dietary intake is a major determinant in the development and progression of high BP. Lifestyle modifications, including recommended dietary guidelines, are advocated by the American Society of Hypertension, the International Society of Hypertension, the Japanese Society of Hypertension, and many other organisations for treating all hypertensive people, prior to initiating drug therapy and as an adjunct to medication in persons already on drug therapy. Lifestyle modification can also reduce high BP and prevent development of hypertension. This review synthesizes results from the International Study of Macro/ Micronutrients and Blood Pressure (INTERMAP), a cross-sectional epidemiological study of 4,680 men and women aged 40-59 years from Japan, the People's Republic of China, the United Kingdom, and the United States, published over the past few years on cross cultural BP differences. INTERMAP has previously reported that intakes of vegetable protein, glutamic acid, total and insoluble fibre, total polyunsaturated fatty acid and linoleic acid, total n-3 fatty acid and linolenic acid, phosphorus, calcium, magnesium, and non-heme iron were inversely related to BP. Direct associations of sugars (fructose, glucose, and sucrose) and sugar-sweetened beverages (especially combined with high sodium intake), cholesterol, glycine, alanine, and oleic acid from animal sources with BP were also reported by the INTERMAP Study.

J Atheroscler Thromb, 2016; 23: 276-289.

Key words: Blood pressure, Diet, Guideline, Hypertension, INTERMAP, Management, Nutrient, Prevention

\section{Introduction}

Adverse blood pressure (BP), including prehypertensive [defined as systolic blood pressure (SBP) of 120 to $139 \mathrm{mmHg}$ or a diastolic blood pressure (DBP) of 80 to $89 \mathrm{mmHg}]^{1)}$ and hypertensive

Address for correspondence: Paul Elliott, Department of Epidemiology and Biostatistics, School of Public Health, Imperial College London, Norfolk Place, London, W2 1PG, UK.

Email: p.elliott@imperial.ac.uk

Received: October 24, 2015

Accepted for publication: November 11, 2015 [defined as $\mathrm{SBP} \geq 140 \mathrm{mmHg}$ and/or $\mathrm{DBP} \geq 90$ $\mathrm{mmHg}$ and/or current use of antihypertensive medication] levels ${ }^{1,2)}$, is a key independent risk factor for major cardiovascular diseases (CVD), afflicting a high and growing proportion of the adult population worldwide ${ }^{3-6)}$. Overall, an estimated $26 \%$ of the world's adult population were hypertensive in 2000 and $29 \%$ are projected to have hypertension (HTN) by $2025^{7}$. Health policies dependent on antihypertensive drugs alone are only partially successful as many persons with established HTN do not take medication or do not take enough medication to 
achieve control ${ }^{8-10)}$, while the large numbers of people with BP in the normal, but not optimal, and highnormal range go untreated. A challenge is how to set up an effective population-wide strategy to stem the $\mathrm{BP}$ rise with age and to reduce overall $\mathrm{BP}$ levels, and in turn, reduce cardiovascular morbidity and mortality. Lifestyle modification including adherence to evidence-based dietary guidelines is recommended in HTN management and included within prevention guidelines advocated by the American Society of Hypertension (ASH), the European Society of Hypertension, the International Society of Hypertension (ISH), and many other organisations for treatment of all hypertensive people and prevention among those with a strong family history of $\mathrm{HTN}^{1,2,11-16)}$.

Dietary intake is a major determinant in the development and progression of high $\mathrm{BP}^{6}$. Dietary factors identified as being associated with $\mathrm{BP}$ in the INTERnational study of MAcro/micronutrients and blood Pressure (INTERMAP) are reported here (surveyed 1996-1999) and placed in the context of the available literature.

\section{Evidence Prior To the INTERMAP Study}

Lifestyle modification offers the potential for preventing development of raised BP and frank HTN and can lower BP at little cost and with minimal risk ${ }^{17)}$. The INTERSALT Study in 1988 reported that sodium $(\mathrm{Na})$ intake, body mass index (BMI) and excessive alcohol intake were all directly associated with BP, while potassium (K) was inversely associated $^{18-21)}$. These findings were reflected in dietary recommendations for management and prevention of high $\mathrm{BP}^{22)}$ : reduction of $\mathrm{Na}$ intake ${ }^{23)}(<100 \mathrm{mmol} /$ day); restriction of alcohol intake ${ }^{24)}(<30 \mathrm{ml} /$ day ethanol for men and $<15 \mathrm{ml} /$ day ethanol for women); and maintenance of adequate $\mathrm{K}$ intake $\left.{ }^{25}\right)(90 \mathrm{mmol} /$ day). Other lifestyle modifications recommended included weight reduction (body mass index $<27 \mathrm{~kg} /$ $\mathrm{m}^{2}$ ), regular physical activity and tobacco avoidance $^{22)}$. There were no recommended intakes of calcium $(\mathrm{Ca})$, magnesium $(\mathrm{Mg})$, cholesterol or fatty acids (e.g. n-3 fatty acids) though favourable intakes of these nutrients may further contribute to lowering BP.

\section{The INTERMAP Study-Design and Methods}

The INTERMAP Study is a cross-sectional epidemiological study of 4,680 men and women aged 40-59 years from 17 population samples (Fig. 1) in Japan, the People's Republic of China, the United Kingdom and the United States (www.clinicaltrials. gov NCT00005271) ${ }^{26)}$. Participants were selected randomly from population lists, stratified by age/sex. Staff were trained, standardized and certified for BP measurement on the basis of a common protocol ${ }^{26)}$. Each participant attended four visits, visits 1 and 2 on consecutive days, visits 3 and 4 on consecutive days on average 3 weeks later. For BP measurement, each participant-having emptied his/her bladder-was seated comfortably for $5 \mathrm{~min}$, with no physical activity in the preceding half hour. BP was measured twice at each visit with a random zero sphygmomanometer. Korotkoff sounds I and V were criteria for SBP and DBP. Measurements of height and weight were obtained at two visits, as were questionnaire data on daily alcohol consumption over the previous 7 days. Dietary data were collected at each visit by a trained certified interviewer with use of the in-depth multipass $24-\mathrm{h}$ recall method ${ }^{27)}$. All foods, beverages, and supplements consumed in the previous 24 hours, including preparation methods, were recorded. Each participant provided two $24-\mathrm{h}$ urine collections, start and end timed at the research centre; measurements included urinary volume, $\mathrm{Na}, \mathrm{K}, \mathrm{Mg}, \mathrm{Ca}$, urea and creatinine $^{26)}$, amino acids ${ }^{28)}$, and proton nuclear magnetic resonance $\left({ }^{1} \mathrm{H}\right.$ NMR) spectroscopy ${ }^{29)}$. For external estimation of laboratory precision, a random $10 \%$ of samples were split locally and sent to the laboratory with different identification numbers. Questionnaire data were obtained on demographic and other possible confounders, including education, occupation, physical activity, cigarette smoking, history of CVD, or diabetes mellitus (DM), current use of a special diet, and use of antihypertensive and lipid-lowering drugs. Individuals were excluded if they did not attend all four visits; diet data were considered unreliable; energy intake from any 24-h dietary recall was $<500 \mathrm{kcal} /$ day or $>5000 \mathrm{kcal} /$ day for women, $>8000 \mathrm{kcal} /$ day for men; two urine collections were not available; data on other variables were incomplete or indicated protocol violation (total exclusions: 215 people) ${ }^{30)}$. The study received institutional ethics committee approval for each site; all participants gave written informed consent.

\section{Individual Nutrients and Blood Pressure}

The INTERMAP Study reported that intakes of vegetable (plant) protein ${ }^{30)}$, glutamic acid ${ }^{31)}$, total and insoluble fibre ${ }^{32)}$, total polyunsaturated fatty acid (PUFA) and linoleic acid ${ }^{33)}$, oleic acid from vegetable sources $^{34)}$, total n-3 fatty acid and linolenic acid ${ }^{35)}$, phosphorus (P), $\mathrm{Ca}$ and $\mathrm{Mg}^{36)}$, non-heme iron $(\mathrm{Fe})$ and total $\mathrm{Fe}^{37)}$, and $\operatorname{starch}^{38)}$ were inversely related to 

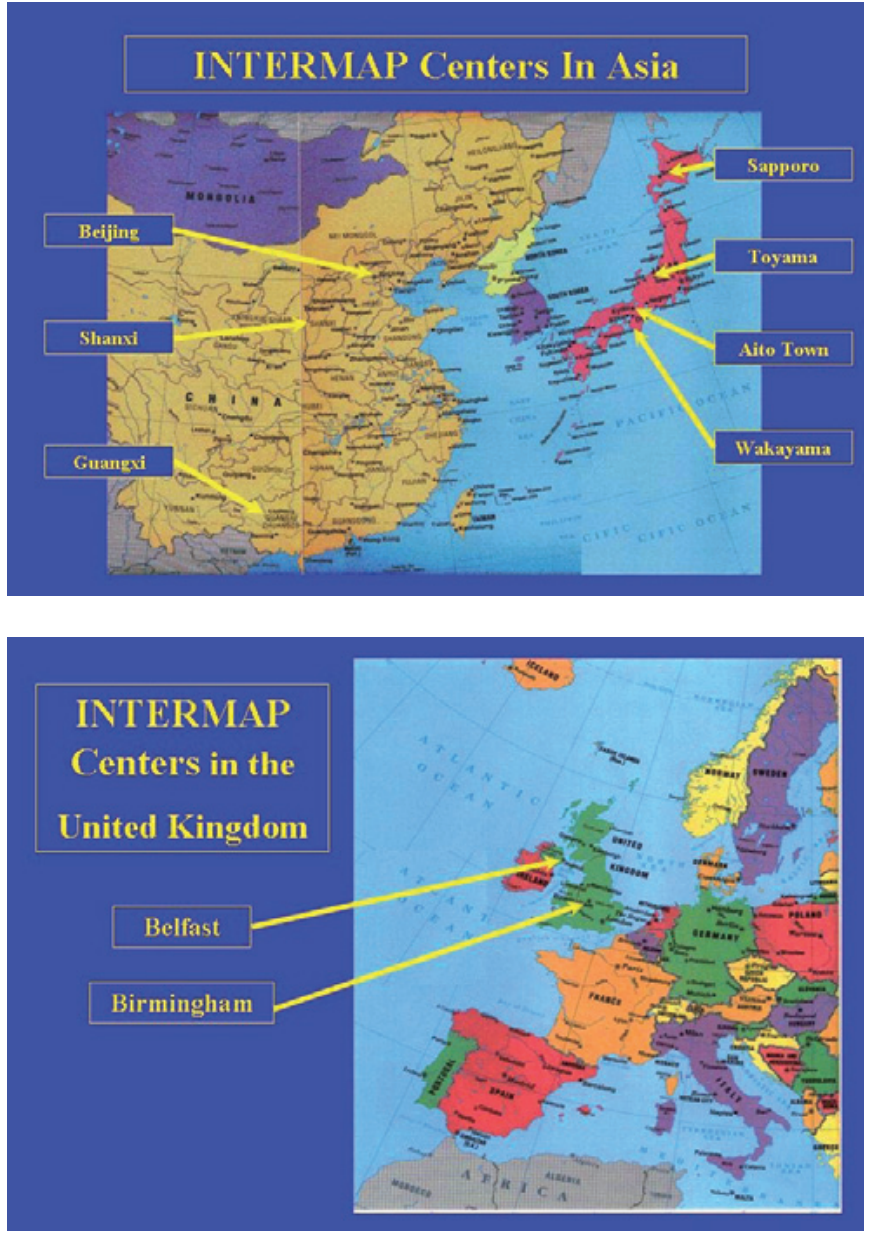

BP. Direct associations of sugars (fructose, glucose, and sucrose $)^{39)}$, cholesterol ${ }^{40)}$, glycine and alanine ${ }^{41)}$, and oleic acid from animal sources ${ }^{34)}$ with $\mathrm{BP}$ were also reported by the INTERMAP Study. Findings of individual nutrients and BP of the INTERMAP Study are summarized in Table $\mathbf{1}$ and in the following sections.

\section{Protein and Amino Acids}

As noted above, the relationship between individuals' vegetable protein intake and $\mathrm{BP}$ was inverse (SBP difference with 2 standard deviation (SD) higher vegetable protein intake was $-1.1 \mathrm{mmHg}, P<0.01$ ); while for animal protein, there was significant direct associations with BP, which did not persist after adjustment for height and weight; there was no significant association between total protein intake and $\mathrm{BP}^{30)}$. The INTERMAP Study subsequently reported that glutamic acid, the predominant dietary amino acid (especially in vegetable protein), was inversely associated with BP (SBP difference $-1.1 \mathrm{mmHg}$ for 2SD higher glutamic acid intake (4.72\%total protein), $P<0.05)^{31)}$. Dietary glycine and alanine levels

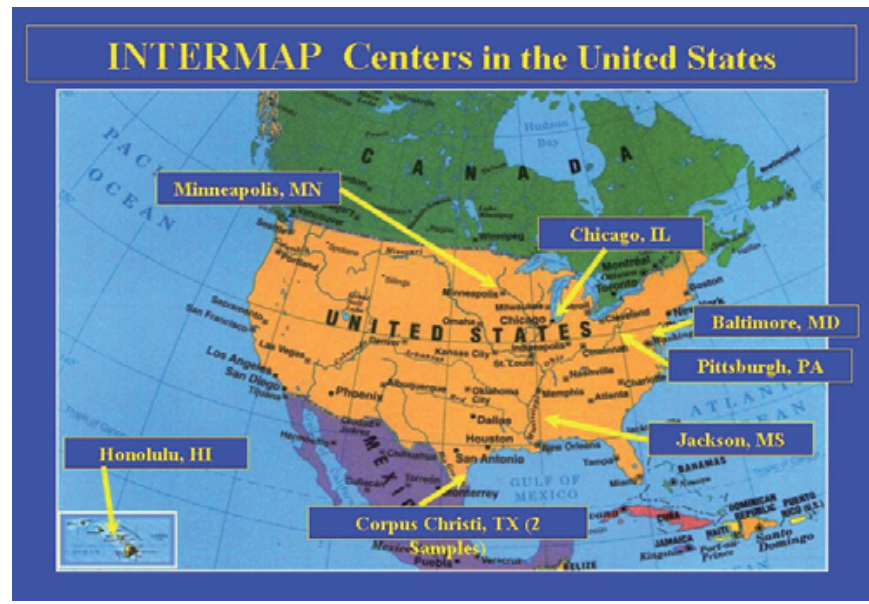

Fig. 1. Locations of the field centres in Japan, People's Republic of China, UK and USA, the INTERAMP Study ${ }^{26}$

Maps reproduced courtesy of Rand McNally \& Company, Skokie, IL, USA, from the Rand McNally Classroom Atlas.

(predominant in animal protein) had independent direct relations to BP: glycine intake higher by 2SD $(0.89 \%$ total protein) was associated with differences of $2.0 \mathrm{mmHg}(P<0.001)$ for $\mathrm{SBP}^{41)}$. Systematic reviews have suggested a small beneficial effect of protein on BP, especially for plant protein ${ }^{42,43)}$. A metaanalysis of randomized controlled trials (RCTs) with 32 comparisons between protein and carbohydrate found that dietary protein intake increased on average by $40 \mathrm{~g} /$ day lower mean SBP and DBP by -1.8 $\mathrm{mmHg}$ and $-1.1 \mathrm{mmHg}$, respectively (both $P<$ $0.001)$, with no heterogeneity in BP reduction based on protein source ${ }^{44)}$. A meta-analysis (2013) of observational studies and RCTs showed a small inverse association of total protein with $\mathrm{BP}$, but a non-significant inverse association was found for plant protein ${ }^{45)}$. The analysis reported a pooled estimate of -0.2 $\mathrm{mmHg}(95 \%$ confidence interval [CI] -0.4 to 0.01 ) systolic per $25 \mathrm{~g}$ of total protein intake in 6 cross-sectional studies; in 14 intervention studies using carbohydrate as a control treatment, the pooled $\mathrm{BP}$ effect was $-2.1 \mathrm{~mm}$ systolic $(-2.9$ to -1.4$)$ for a 
Table 1. Mean difference in blood pressure with dietary intakes higher by 2 standard derivations, regression model ${ }^{\S}$ for all INTERMAP participants $(N=4,680)$

\begin{tabular}{|c|c|c|c|c|}
\hline Nutrient & 2 SD difference & SBP difference $(\mathrm{mmHg})$ & DBP difference (mmHg) & Note \\
\hline Vegetable protein $^{30)}$ & $2.80 \% \mathrm{kcal}$ & $\begin{array}{l}-1.11^{* *} \\
-1.24^{*} \\
\end{array}$ & $\begin{array}{l}-0.71^{*} \\
-0.86^{*}\end{array}$ & (i) \\
\hline Animal protein ${ }^{30)}$ & $5.84 \% \mathrm{kcal}$ & 0.20 & -0.02 & \\
\hline Glutamic acid $^{31)}$ & $1.00 \% \mathrm{kcal}$ & $-1.08^{*}$ & $-0.66^{*}$ & (c) \\
\hline Glycine $^{41)}$ & $\begin{array}{c}0.89 \% \text { total protein } \\
0.31 \% \mathrm{kcal}\end{array}$ & $\begin{array}{l}2.03^{* * *} \\
0.42 \\
\end{array}$ & $\begin{array}{l}0.89^{* *} \\
0.15\end{array}$ & (c) \\
\hline Alanine $^{41)}$ & $\begin{array}{c}0.85 \% \text { total protein } \\
0.34 \% \mathrm{kcal}\end{array}$ & $\begin{array}{r}1.32^{*} \\
-0.18 \\
\end{array}$ & $\begin{array}{r}0.38 \\
-0.17 \\
\end{array}$ & (c) \\
\hline Total polyunsaturated fatty acid ${ }^{33)}$ & $4.04 \% \mathrm{kcal}$ & $\begin{array}{l}-0.38 \\
-1.35^{*}\end{array}$ & $\begin{array}{l}-0.34 \\
-0.88^{*}\end{array}$ & (j) \\
\hline 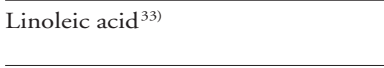 & $3.77 \% \mathrm{kcal}$ & $\begin{array}{l}-0.39 \\
-1.36^{*}\end{array}$ & $\begin{array}{l}-0.31 \\
-0.83^{*}\end{array}$ & (j) \\
\hline Total n-3 fatty acid ${ }^{35)}$ & $0.67 \% \mathrm{kcal}$ & $\begin{array}{l}-0.55 \\
-1.01 \\
-0.74^{*}\end{array}$ & $\begin{array}{l}-0.57^{*} \\
-0.98^{*} \\
-0.72^{*}\end{array}$ & $\begin{array}{l}(a) \\
(a, j) \\
(a, k)\end{array}$ \\
\hline Linolenic acid ${ }^{35)}$ & $0.57 \% \mathrm{kcal}$ & $\begin{array}{l}-0.60 \\
-0.97 \\
-0.77^{*}\end{array}$ & $\begin{array}{l}-0.50 \\
-0.87 \\
-0.61^{*}\end{array}$ & $\begin{array}{l}(\mathrm{j}) \\
(\mathrm{k})\end{array}$ \\
\hline Monounsaturated fatty acid ${ }^{34)}$ & $5.35 \% \mathrm{kcal}$ & $\begin{array}{r}0.05 \\
-1.22 \\
\end{array}$ & $\begin{array}{l}-0.84^{*} \\
-1.54^{*}\end{array}$ & $\begin{array}{l}(\mathrm{e}) \\
(\mathrm{e}, \mathrm{j})\end{array}$ \\
\hline Oleic acid from vegetable sources ${ }^{34)}$ & $4.12 \% \mathrm{kcal}$ & $\begin{array}{l}-0.84^{*} \\
-1.28^{*} \\
\end{array}$ & $\begin{array}{l}-0.65^{*} \\
-1.01^{*}\end{array}$ & $\begin{array}{c}(e) \\
(e, j)\end{array}$ \\
\hline Oleic acid from animal sources ${ }^{34)}$ & $3.86 \% \mathrm{kcal}$ & $\begin{array}{l}2.47^{* * *} \\
1.80 \\
\end{array}$ & $\begin{array}{l}0.94^{*} \\
1.22 \\
\end{array}$ & $\begin{array}{c}(j) \\
(e, j)\end{array}$ \\
\hline Starch $^{38)}$ & $14.11 \% \mathrm{~kJ}$ & $\begin{array}{l}-0.57 \\
-0.96 \\
-1.52\end{array}$ & $\begin{array}{l}-0.52 \\
-0.92^{*} \\
-1.23^{*}\end{array}$ & $\begin{array}{l}(\mathrm{b}) \\
(\mathrm{b}, \mathrm{j})\end{array}$ \\
\hline Fructose $^{39)}$ & $5.60 \% \mathrm{kcal}$ & $\begin{array}{l}0.73 \\
1.07 \\
2.50^{* * *}\end{array}$ & $\begin{array}{l}0.44 \\
0.62 \\
1.71^{* *}\end{array}$ & $\begin{array}{c}(\mathrm{l}) \\
(\mathrm{c}, \mathrm{l}) \\
(\mathrm{c}, \mathrm{l}, \mathrm{o})\end{array}$ \\
\hline Glucose $^{39)}$ & $5.10 \% \mathrm{kcal}$ & $\begin{array}{l}0.75 \\
1.08^{*} \\
2.69^{* * *}\end{array}$ & $\begin{array}{l}0.44 \\
0.60 \\
1.61^{* *}\end{array}$ & $\begin{array}{c}(\mathrm{l}) \\
(\mathrm{c}, \mathrm{l}) \\
(\mathrm{c}, \mathrm{l}, \mathrm{o})\end{array}$ \\
\hline Sucrose $^{39)}$ & $9.80 \% \mathrm{kcal}$ & $\begin{array}{l}0.21 \\
0.33 \\
\end{array}$ & $\begin{array}{l}0.71^{*} \\
0.74^{*}\end{array}$ & $\begin{array}{c}(1) \\
(c, 1)\end{array}$ \\
\hline Total fibre ${ }^{32)}$ & $\begin{array}{l}6.80 \mathrm{~g} / 1000 \mathrm{kcal} \\
6.90 \mathrm{~g} / 1000 \mathrm{kcal}\end{array}$ & $\begin{array}{l}-1.01 \\
-1.69^{* *}\end{array}$ & $\begin{array}{l}-0.42 \\
-1.15 \\
\end{array}$ & $\begin{array}{l}(\mathrm{f}, \mathrm{m}) \\
(\mathrm{f}, \mathrm{n})\end{array}$ \\
\hline Insoluble fibre ${ }^{32)}$ & $\begin{array}{l}4.60 \mathrm{~g} / 1000 \mathrm{kcal} \\
4.80 \mathrm{~g} / 1000 \mathrm{kcal}\end{array}$ & $\begin{array}{l}-1.81 \\
-2.48^{* *}\end{array}$ & $\begin{array}{l}-1.16^{*} \\
-3.51^{* *}\end{array}$ & $\begin{array}{l}(\mathrm{g}, \mathrm{m}) \\
(\mathrm{g}, \mathrm{n})\end{array}$ \\
\hline Soluble fibre ${ }^{32)}$ & $\begin{array}{l}2.20 \mathrm{~g} / 1000 \mathrm{kcal} \\
2.20 \mathrm{~g} / 1000 \mathrm{kcal}\end{array}$ & $\begin{array}{l}0.88 \\
0.89\end{array}$ & $\begin{array}{r}0.68 \\
-0.47\end{array}$ & $\begin{array}{l}(\mathrm{h}, \mathrm{m}) \\
(\mathrm{h}, \mathrm{n})\end{array}$ \\
\hline Cholesterol $^{40)}$ & $131.0 \mathrm{mg} / 1000 \mathrm{kcal}$ & $\begin{array}{l}0.94^{*} \\
1.42^{* *} \\
1.46^{* *}\end{array}$ & $\begin{array}{l}0.24 \\
0.37 \\
0.66^{*}\end{array}$ & $\begin{array}{c}(\mathrm{d}) \\
(\mathrm{d}, \mathrm{k})\end{array}$ \\
\hline Phosphorus ${ }^{36)}$ & $232.0 \mathrm{mg} / 1000 \mathrm{kcal}$ & $\begin{array}{l}-1.36^{* *} \\
-1.64^{*}\end{array}$ & $\begin{array}{l}-0.94^{* *} \\
-1.13^{*}\end{array}$ & (j) \\
\hline Calcium $^{36)}$ & $240.2 \mathrm{mg} / 1000 \mathrm{kcal}$ & $-1.48^{* * *}$ & $-0.97^{* *}$ & \\
\hline Magnesium ${ }^{36)}$ & $75.6 \mathrm{mg} / 1000 \mathrm{kcal}$ & $-1.51^{* *}$ & -0.61 & \\
\hline Total Iron ${ }^{37)}$ & $4.20 \mathrm{mg} / 4.2 \mathrm{MJ}$ & $-1.44^{* * *}$ & $-0.71^{* *}$ & \\
\hline Non-haem Iron ${ }^{37)}$ & $4.13 \mathrm{mg} / 4.2 \mathrm{MJ}$ & $-1.51^{* * *}$ & $-0.75^{* *}$ & \\
\hline Haem Iron ${ }^{37)}$ & $0.61 \mathrm{mg} / 4.2 \mathrm{MJ}$ & 0.19 & 0.10 & \\
\hline
\end{tabular}

$\$$ Adjustment for population sample, age, sex, special diet, history of cardiovascular disease (CVD) or diabetes mellitus (DM), family history of Adjustment for population sample, age, sex, special diet, history of cardiovascular disease (CVD) or diabetes mellitus (DM), family history of
hypertension, moderate or heavy physical activity (usual hours per day), dietary supplement intake, 24-h urinary sodium (Na) and potassium excretion and 7 day alcohol intake with either height and weight or body mass index ${ }^{*} p<0.05 ;{ }^{* *} p<0.01 ;{ }^{* * *} p<0.001$

(a) Regression model with additional adjustment for cholesterol, saturated fatty acid (SFA), calcium (Ca) and phosphorus (P)

(b) Regression model with additional adjustment for cholesterol, SFA, polyunsaturated fatty acid (PUFA) and Ca

(c) Regression model with additional adjustment for cholesterol, SFA and PUFA

(d) Regression model with additional adjustment for SFA, PUFA and P

(e) Regression model with additional adjustment for cholesterol, SFA, and Ca

(f) Regression model with additional adjustment for total energy, total protein, total fat, total sugar

(g) Regression model with additional adjustment for total energy, total protein, total fat, total sugar, soluble fibre

(h) Regression model with additional adjustment for total energy, total protein, total fat, total sugar, insoluble fibre

(i) Excluding persons taking hypertensive or cardiovascular disease medications $(\mathrm{N}=3,930)$

(j) Non-intervened persons only (individuals not on a special diet, not consuming nutritional supplements, not with diagnosed CVD/diabetes, not taking medication for high $\mathrm{BP} / \mathrm{CVD} /$ diabetes) and regressions not adjusted for special diet, supplement use, or CVD-DM ( $N=2,238$ )

$\begin{array}{ll}\text { (k) Non-hypertensive persons only }(N=3,671) & \text { (l) UK and US participants only }(N=2,696)\end{array}$

$\begin{array}{ll}\text { (m) US participants only }(N=2,195) & \text { (n) Non-hypertensive US participants only }(N=1,477)\end{array}$

(o) With Na excretion > median values: UK men, $>155 \mathrm{mmol} / 24-\mathrm{h}$; UK women, $>125 \mathrm{mmol} / 24-\mathrm{h}$; USA men, > 174 mmol/24-h; USA women, $>137 \mathrm{mmol} / 24-\mathrm{h}(N=1,347)$ 
mean contrast in protein intake of $41 \mathrm{~g} /$ day. However, the associations of plant protein and animal protein with BP were broadly similar in prospective studies and RCTs. The BP effect of specific types of protein remains to be established.

\section{Fatty Acids and Fish Oils}

Participants in the INTERMAP Study who reported a higher intake of n-3 PUFA (rich in fish oil) had lower BP levels ${ }^{35)}$. The study also reported an inverse association of linoleic acid (the main dietary PUFA) with $\mathrm{BP}^{33)}$. Meta-analyses of RCTs on fish oil supplements reported significant BP reduction overall and in hypertensive participants ${ }^{46,47)}$. The analyses (1993) showed that, compared to control groups, pooled estimates of SBP and DBP change were -1.0 $\mathrm{mmHg}(95 \% \mathrm{CI}-2.0$ to 0.0$)$ and $-0.5 \mathrm{mmHg}$ (1.2 to 0.2$)$ in normotensive individuals, and -5.5 $\mathrm{mmHg}(-8.1$ to -2.9$)$ and $-3.5 \mathrm{mmHg}(-5.0$ to -2.1 ) in untreated hypertensive individuals with an average of $>3 \mathrm{~g} /$ day $\mathrm{n}-3$ PUFA supplementation ${ }^{46)}$. Fish oil supplementation (median of $3.7 \mathrm{~g} /$ day) was reported to reduce SBP by $2.1 \mathrm{mmHg}(95 \%$ CI 1.0 to 3.2 ) and DBP by $1.6 \mathrm{mmHg}$ (1.0 to 2.2), compared to placebo, in meta-analysis of 36 RCTs $(2002)^{47)}$. A review (2006) of RCTs of linolenic acid supplementation showed no significant difference in BP changes between participants taking supplementation compared to placebo control groups ${ }^{48)}$. Other INTERMAP Study findings include inverse associations of monounsaturated fatty acid (MUFA), total oleic acid (main MUFA) and oleic acid from vegetable sources with $\mathrm{BP}^{34)}$. A review (2006) of studies conducted in the Mediterranean countries reported that MUFA was inversely associated with BP; this contrasts with earlier studies conducted mainly in the USA and Northern Europe $^{49)}$. This may due to the difference on food sources of MUFA: dairy, nut butter and meat for the western diet, and olives and olive oil for the traditional Mediterranean diet (MetDiet) ${ }^{50)}$. A meta-analysis of 9 RCTs (2011) comparing a high MUFA diet to a low MUFA diet reported significant reduction on $\mathrm{BP}^{51)}$. The pooled effect of a high-MUFA diet was -2.3 $\mathrm{mmHg}(95 \% \mathrm{CI}-4.3$ to -0.3$)$ for SBP. Another meta-analysis of 13 RCTs (2014) reported studies examined effect of total amount of fat and the quality of fat (proportions of SFA, MUFA or total unsaturated fat) on $\mathrm{BP}$ but results were inconsistent and no conclusions could be drawn ${ }^{52)}$.

\section{Starch and Sugars}

Among the participants of the INTERMAP study, there were modest inverse associations of starch intake and BP, which were attenuated by control for vegetable protein ${ }^{38)}$. Findings from the Multiple Risk Factor Intervention Trial (MRFIT) reported a direct association between dietary starch intake and $\mathrm{BP}^{53)}$. A meta-analysis of 10 studies (2007) comparing the effects of high-carbohydrate versus high-MUFA diets indicated that the high-carbohydrate diets were associated with significantly higher BP (mean SBP difference $2.6 \mathrm{mmHg}, P=0.02)^{54)}$.

The INTERMAP Study reported direct fructoseand glucose-BP associations, with significant sugarsodium interactions: for individuals with abovemedian 24-h urinary $\mathrm{Na}$ excretion, fructose intake higher by $2 \mathrm{SD}(5.6 \% \mathrm{kcal})$ was associated with systolic/diastolic BP differences of $2.5 / 1.7 \mathrm{mmHg}^{39)}$. A meta-analysis of 13 RCTs of isocaloric diets (2012) with a median follow-up of 4 weeks found a significant DBP-lowering effect when fructose was substituted for other carbohydrates (mean difference -1.5 $\mathrm{mmHg}, 95 \% \mathrm{CI}-2.8$ to -0.3$)$ but no significant effect on SBP ${ }^{55)}$. A meta-analysis of 7 studies (2014) showed that fructose consumption was positively associated with elevated SBP $(0.3 \mathrm{mmHg}, P=0.002)$ and there was statistically significant heterogeneity among studies $\left(\mathrm{I}^{2}=83.4 \%, P=0.001\right)^{56}$. Another review of 12 RCTs (2014) reported no significant effect of higher sugar intakes on SBP and a significantly greater $\mathrm{DBP}$ of $1.4 \mathrm{mmHg}(P=0.02)$; a significant and positive association of sugar intake with $\mathrm{BP}$ was found in a subgroup of 3 trials $>8$ weeks in duration (mean difference: $6.9 \mathrm{mmHg}$ for SBP, $P<0.0001$ and 5.6 $\mathrm{mmHg}$ for DBP, $P<0.001)^{57)}$.

\section{Fibre}

The INTERMAP Study reported higher intake of total dietary fibre, especially insoluble, was associated with lower $\mathrm{BP}^{32)}$. A meta-analysis (2005) of 25 RCTs demonstrated the hypotensive effects of dietary fibre in hypertensive persons $(\mathrm{SBP}-6.0 \mathrm{mmHg}$ and DBP $-4.2 \mathrm{mmHg}$ per $10.7 \mathrm{~g} /$ day total fibre on average, both $P<0.001$ ) while in normotensive individuals, there was a smaller, non-significant reduction in $\mathrm{BP}^{58)}$. Another meta-analysis in the same year investigating the effect of fibre supplementation (average dose of $11.5 \mathrm{~g} /$ day) on BP from $24 \mathrm{RCTs}$ reported a small BP-lowering effect of $-1.1 \mathrm{mmHg}(95 \% \mathrm{CI}$ -2.5 to 0.2$) \mathrm{SBP}$ and $-1.3 \mathrm{mmHg}(-2.0$ to -0.5$)$ $\mathrm{DBP}^{59)}$. A recent review (2015) of RCTs of 7 types of fibre (e.g., arabinoxylan from wholegrain foods, betaglucan from oats and barley) reported that higher consumption of fibre was associated with lower BP, and diets rich in beta-glucan reduced SBP by $2.9 \mathrm{mmHg}$ (95\% CI 0.2 to 2.7 ) and DBP by $1.5 \mathrm{mmHg}$ (0.2 to 
2.7) for a median difference in beta-glucan of $4 \mathrm{~g}^{60)}$.

\section{Phosphorus}

The INTERMAP Study showed that higher P intake (per 2SD of $232.0 \mathrm{mg} / 1000 \mathrm{kcal}$ ), independently of other nutrients, was associated with lower BP levels $(-1.4 \mathrm{mmHg}$ for SBP, $-0.9 \mathrm{mmHg}$ for DBP, both $P<0.01)^{36}$. A study using dietary data for 13,444 participants from Atherosclerosis Risk in Communities cohort and the Multi-Ethnic Study of Atherosclerosis reported $P$ intake (per $500 \mathrm{mg} /$ day higher) was inversely associated with SBP (-2.1 $\mathrm{mmHg}, 95 \% \mathrm{CI}-1.1$ to -3.0$)$, after adjustment for confounders and highly correlated nutrients ${ }^{61)}$.

\section{Calcium and Magnesium}

Epidemiological data have shown that both dietary and supplemental $\mathrm{Ca}$ are associated with small reductions in BP. For all 4,680 INTERMAP participants, estimated BP differences for dietary $\mathrm{Ca}$ higher by $240.2 \mathrm{mg} / 1000 \mathrm{kcal}$ (2SD) was $-1.5 \mathrm{mmHg}$ for SBP $(P<0.001)$ and $-1.0 \mathrm{mmHg}$ for DBP $(P<$ $0.01)^{36)}$. A meta-analysis of 22 RCTs (1996) reported an inverse relationship of Ca supplement on BP; overall pooled estimated of $\mathrm{Ca}$ supplementation were -0.9 $\mathrm{mmHg}(95 \% \mathrm{CI}-1.74$ to -0.05$)$ for SBP and it was $-1.7 \mathrm{mmHg}(-3.2$ to -0.2$)$ for hypertensive persons ${ }^{62)}$. Another pooled meta-analysis of RCTs of $\mathrm{Ca}$ supplements (1999) also reported a reduction in SBP of $1.4 \mathrm{mmHg}$ and in DBP of $0.8 \mathrm{mmHg}$ (both $P<$ $0.001)^{63)}$. Similar results were reported in a meta-analysis of 40 RCTs (2006); mean daily dose of 1,200 mg Ca supplementation reduced SBP by $-1.9 \mathrm{mmHg}$ (95\% CI, -2.9 to -0.8 ) and DBP by $-1.0 \mathrm{mmHg}$ $(-1.6 \text { to }-0.4)^{64)}$. A Cochrane review (2006) of 13 RCTs with between 8 and 15 weeks follow-up found that $\mathrm{Ca}$ supplementation was associated with a small statistically significant reduction in SBP (mean difference $-2.5 \mathrm{mmHg}$ ) but had little effect on $\mathrm{DBP}^{65)}$.

The INTERMAP Study suggested an inverse association between dietary $\mathrm{Mg}$ and $\mathrm{BP}$, for dietary $\mathrm{Mg}$ higher by $75.6 \mathrm{mg} / 1000 \mathrm{kcal}$ (2SD), the estimated BP differences were $-1.5 \mathrm{mmHg}$ for SBP $(P<$ $0.01)$ and $-0.6 \mathrm{mmHg}$ for $\mathrm{DBP}^{36)}$. An early metaanalysis (1998) of 29 studies reported a negative correlation between dietary $\mathrm{Mg}$ intake and $\mathrm{BP}^{66)}$. Subsequently, a meta-analysis of $20 \mathrm{RCT}$ s reported $\mathrm{Mg}$ supplementation resulted in only a small overall reduction in BP: estimates of BP change relative to placebo were $-0.6 \mathrm{mmHg}(95 \% \mathrm{CI}-2.2$ to 1.0$)$ for SBP and $0.8 \mathrm{mmHg}(-1.9$ to 0.4$)$ for DBP for average $\mathrm{Mg}$ increase of $367.6 \mathrm{mg} /$ day $^{67)}$. There was a dose-dependent effect of $\mathrm{Mg}$, with reduction of $4.3 \mathrm{mmHg}$ SBP
$(P<0.001)$ and of $2.3 \mathrm{mmHg} \operatorname{DBP}(P=0.09)$ for each $238.7 \mathrm{mg} /$ day increase in $\mathrm{Mg}$. In 2006, a Cochrane review of 12 RCTs with 8 to 26 weeks follow-up reported that supplemental $\mathrm{Mg}$ and lowered DBP (though not SBP): mean difference $-2.2 \mathrm{mmHg}$ DBP $(95 \%$ CI -3.4 to -0.9$)$. However, there was marked heterogeneity between studies $\left(\mathrm{I}^{2}=47.0 \%\right)^{68)}$.

A prospective study of $>136,000$ Chinese men and women reported that persons with $\mathrm{Ca} / \mathrm{Mg}$ ratios above the median $(>1.7)$, intakes of $\mathrm{Ca}(\geq 600 \mathrm{mg} /$ day) and $\mathrm{Mg}$ ( $\geq 320 \mathrm{mg} /$ day) were associated with reduced risks of total mortality, and mortality due to coronary heart disease; conversely, participants with a $\mathrm{Ca} / \mathrm{Mg}$ ratio $\leq 1.7$, intake of $\mathrm{Mg}$ was associated with increased risks of total mortality and mortality due to $\mathrm{CVD}^{69)}$. The mean intake of $\mathrm{Mg}$ in Chinese population was similar to the US populations whereas the $\mathrm{Ca} / \mathrm{Mg}$ intake ratio was significantly lower compared to US populations (3.0); the findings suggested that dietary $\mathrm{Ca} / \mathrm{Mg}$ ratio, not $\mathrm{Mg}$ or $\mathrm{Ca}$ intake alone, might contribute to the different incidence and risks of mortality ${ }^{69)}$.

\section{Iron}

The INTERMAP Study suggested an inverse association of total Fe intake and non-heme Fe intake with $\mathrm{BP}^{37)}$. Dietary total $\mathrm{Fe}$ intake higher by 4.20 $\mathrm{mg} / 4.2 \mathrm{MJ}(2 \mathrm{SD})$ was associated with $-1.4 \mathrm{mmHg}(P$ $<0.001)$ SBP and non-heme Fe intake higher by 4.1 $\mathrm{mg} / 4.2 \mathrm{MJ}$ (2SD) was associated with $-1.5 \mathrm{mmHg}(P$ $<0.001)$ SBP. A follow-up study of 2,895 participants reported similar findings; low non-heme Fe intake at baseline was associated with a greater increase in SBP over time $(P$-trend $=0.002)$ and participants in the top tertile of non-heme Fe intake at baseline had a significantly lower risk of HTN after 5.4 y of follow-up compared with those in the bottom tertile ${ }^{70)}$. However, the relationship between Fe intake and raised $\mathrm{BP}$ or risk of CVD is not well established in the literature. A review of 55 studies (2013) suggested there was not a high level of evidence supporting the hypothesis that the Fe may be associated with $\mathrm{CVD}^{71)}$. A recent metaanalysis (2015) of 13 prospective cohort studies showed higher dietary intake of heme $\mathrm{Fe}(1 \mathrm{mg} /$ day $)$ was associated with an increased risk of CVD (relative risk $[R R]=1.07,95 \%$ CI 1.01 to 1.14 ) and no association between CVD risk and dietary non-heme $\mathrm{Fe}$ $(\mathrm{RR}=0.98,0.96$ to 1.01$)$ or total $\mathrm{Fe}(\mathrm{RR}=1.00,0.95$ to 1.06$)^{72)}$.

\section{Multiple Nutrients}

The INTERMAP Study reported the combined effects of multiple nutrients on BP by assessing multi- 
Table 2. Estimated population-wide lower average systolic blood pressure ( $\mathrm{mmHg}$ ) of more favourable diet, the INTERMAP Study

\begin{tabular}{|c|c|c|c|c|c|}
\hline \multirow[b]{2}{*}{ Variable } & \multirow{2}{*}{$\begin{array}{l}\text { Improvement } \\
\text { in level }\end{array}$} & \multicolumn{4}{|c|}{$\begin{array}{l}\text { Estimated lower average SBP }(\mathrm{mmHg}) \\
\text { Multivariate models with } \mathrm{BMI}^{\S}\end{array}$} \\
\hline & & $\begin{array}{c}\text { Model 1: } \\
\text { Ca, P, } \\
\text { Vegetable Protein }\end{array}$ & $\begin{array}{l}\text { Model 2: } \\
\text { Ca, Non-heme Fe, } \\
\text { Vegetable Protein }\end{array}$ & $\begin{array}{l}\text { Model 3: } \\
\mathrm{Ca}, \mathrm{P}, \mathrm{Mg}\end{array}$ & $\begin{array}{c}\text { Model 4: } \\
\text { Ca, Mg, } \\
\text { Non-heme Fe }\end{array}$ \\
\hline Urinary sodium (mmol/24 h) & -110 & $-0.7^{\ddagger}$ & $-0.7^{*}$ & -0.7 & $-0.7^{\text {क }}$ \\
\hline Calcium, Ca (mg/1000 kcal) & +240 & $-1.4^{*}$ & $-1.2^{* *}$ & $-1.8^{* *}$ & -1.1 \\
\hline Phosphorus, P (mg/1000 kcal) & +232 & -0.5 & -- & -0.2 & -- \\
\hline Magnesium, Mg (mg/1000 kcal) & +76 & -- & -- & $-0.9^{*}$ & $-1.3^{* *}$ \\
\hline $\begin{array}{l}\text { Heavy alcohol intake } \\
\text { Men }>26 \mathrm{~g} / \text { day; Women }>13 \mathrm{~g} / \text { day }\end{array}$ & $\begin{array}{l}\text { Prevalence } \\
\text { None }\end{array}$ & $\begin{array}{l}\left(-3.3^{* * *}\right) \\
-0.6^{\dagger}\end{array}$ & $\begin{array}{l}\left(-3.3^{* * *}\right) \\
-0.5^{\dagger}\end{array}$ & $\begin{array}{l}\left(-3.5^{* * *}\right) \\
-0.6^{\dagger}\end{array}$ & $\begin{array}{l}\left(-3.4^{* * *}\right) \\
-0.6^{\dagger}\end{array}$ \\
\hline Body mass index $\left(\mathrm{kg} / \mathrm{m}^{2}\right)$ & -4 & $-3.4^{* * *}$ & $-3.4^{* * *}$ & $-3.5^{* * *}$ & $-3.5^{* * *}$ \\
\hline Sum-All Variables & -- & -11.2 & -10.9 & -10.4 & -11.0 \\
\hline Sum-Na, K, Alcohol, BMI & -- & -7.5 & -7.4 & -7.6 & -7.7 \\
\hline
\end{tabular}

$\S$ controlled for age, gender, sample, family history of high BP, physical activity, diagnosis of cardiovascular disease/diabetes, use of special diet, dietary supplement use

${ }_{p}<0.10 ;{ }^{*} p<0.05 ;{ }^{* *} p<0.01 ; * * * 00.001$

ple regression models involving various combinations of dietary vegetable protein, $\mathrm{Ca}, \mathrm{Mg}, \mathrm{P}$, non-heme Fe, $\mathrm{Na}, \mathrm{K}$, PUFA and heavy alcohol consumption adjusted for BMI (Table 2) ${ }^{73}$. For all 4,680 INTERMAP participants, improved $\mathrm{Na}$ and $\mathrm{K}$ intakes and elimination of heavy alcohol consumption, gave a combined estimated effect of SBP lower by $7 \mathrm{mmHg}$; with the addition of other dietary variables, the estimated effect on SBP was 2-3 mmHg lower (about 10 $\mathrm{mmHg}$ ).

Using a systematic nutrient-wide association study (NWAS) approach to evaluate multiple associations between a wide range of nutrients and BP, the INTERMAP Study reported inverse associations between BP and intake of B vitamins (folacin, riboflavin, and thiamin) which replicated in National Health And Nutrition Examination Survey data ${ }^{74)}$. Associations of BP with $\mathrm{B}$ vitamins had previously been poorly studied or were not replicated. This systematic evaluation of multiple nutrients also found inverse associations of dietary $\mathrm{P}, \mathrm{Mg}$, and non-heme $\mathrm{Fe}$ intakes with SBP, and previously established direct associations of $\mathrm{Na} / \mathrm{K}$ ratio and alcohol with $\mathrm{BP}$.

In the Dietary Approaches to Stop Hypertension $(\mathrm{DASH})$ trial, participants were randomly assigned to control diet (the average diet in the US), fruits-andvegetables diet (a diet rich in fruits and vegetables), or combination diet (a diet rich in fruits, vegetables, and low-fat dairy products and with reduced saturated and total fat ${ }^{17)}$. The combination diet reduced SBP by $5.5 \mathrm{mmHg}(95 \% \mathrm{CI}-7.4$ to -3.7$)$ more than the control diet did $(P<0.001)^{17)}$. In the DASH-Na trial, participants were randomly assigned to a control diet or the DASH diet; and participants ate foods with 3 different levels of $\mathrm{Na}$ intake ${ }^{75)}$. Reducing the $\mathrm{Na}$ intake from the high to the intermediate level reduced $\mathrm{BP}$ during both the control diet and the DASH diet. The Optimal Macronutrient Intake Trial for Heart Health (OMNIHEART) trial $^{76)}$ reported BP benefits from replacing carbohydrate in the DASH-Na diet with either protein or MUFA. The INTERMAP Study investigated associations of three OMNIHEART-like nutrient profiles with a typical American nutrient profile, using two different statistical meth- 
ods: regression of $\mathrm{BP}$ on a linear OMNIHEART nutrient score calculated for each individual and Bayesian profile regression ${ }^{77)}$. After adjustment for potential confounders, an OMNIHEART score higher by 1 point was associated with differences of $1.0 \mathrm{mmHg}$ for SBP and $-0.5 \mathrm{~mm} \mathrm{Hg}$ for DBP (both $P<0.001)$. In the Bayesian analysis, mean systolic/ diastolic BPs were 111.3/68.4 and 115.2/70.6 mmHg for OMNIHEART and Control profiles, respectively, after controlling for possible confounders, with BP differences of $-3.9 /-2.2 \mathrm{mmHg}$.

\section{Foods and Drinks}

Because people consume foods and beverages, not isolated nutrients, there is a fundamental interest in these associations. The INTERMAP Study collected data on foods, beverages and preparation methods derived from four 24-h dietary recalls provided by all participants. The study reported a significant and inverse relationship between total vegetable intake and BP; estimated average SBP differences associated with raw vegetable intake $(68 \mathrm{~g} / 1000 \mathrm{kcal})$ and cooked vegetable intake $(92 \mathrm{~g} / 1000 \mathrm{kcal})$ were $-1.3 \mathrm{mmHg}$ $(P=0.02)$ and $-0.9 \mathrm{mmHg}(P<0.1)^{78)}$. The commonly consumed individual vegetables, tomatoes, carrots, scallions, peas, and celery, were related significantly inversely to BP. Apples and pears, citrus fruit, and bananas were the most commonly consumed raw fruit among the INTERAMP participants in each country; fruit juice intake was negligible in East Asian samples ${ }^{79)}$. Although there were no consistent associations between raw fruit and fruit juice intakes of individuals and BP, participants with higher raw fruit intakes had lower energy intake, and had lower BP than those with lower intakes. The higher raw fruit consumers in the UK and US had higher intakes of vegetables, low-fat dairy products, fiber-rich cereals and grains compared with lower raw fruit consumers. These INTERMAP findings on fruits and vegetables reinforce current dietary recommendations for HTN management and prevention ${ }^{1,2)}$.

The INTERMAP study reported sugar-sweetened beverage (SSB) intake higher by 1 serving/day $(355 \mathrm{ml} /$ day $)$ was associated with systolic/diastolic BP differences of $1.1 / 0.4 \mathrm{mmHg}(P<0.001 /<0.05)^{39)}$. These direct SSB-BP associations were stronger for the INTERAMP US participants with higher 24-h urinary $\mathrm{Na}$ excretion with significant sugar- $\mathrm{Na}$ interactions in relation to higher BP. The associations of diet beverages with BPs were consistently inverse; diet beverages intake higher by 1 serving/day was associated with systolic/diastolic BP differences of $-0.6 /-0.4$ $\mathrm{mmHg}$ (both $P<0.05)^{39)}$. A recent review (2014) of studies reported a positive relation between increased SSB intake and high BP; 5 reported an increase in mean BP whereas 7 reported an increase in the incidence of high BP. Dietary guidelines to reduce sugar intake and SSB consumption potentially will have major beneficial effects to prevent $\mathrm{HTN}^{80}$ and $\mathrm{CVD}^{81)}$.

\section{Dietary Guidelines for Management and Prevention of High Blood Pressure}

The DASH-Na diet is a well-balanced approach to prevent and control HTN ${ }^{17,75)}$. It is recommended as part of the HTN guidelines from Canada ${ }^{82)}$, India ${ }^{83)}$, Japan ${ }^{14)}$, the $\mathrm{UK}^{2)}$ and the US ${ }^{1)}$. It is also associated with lower risk of several types of cancer ${ }^{84,85)}$, and reduced risk of developing type 2 diabetes ${ }^{86}$. The MedDiet has also been advocated as a means to reduce $\mathrm{BP}$ and risk of $\mathrm{CVD}^{87)}$. It is characterized by a high intake of olive oil, fruit, nuts, and vegetables; a moderate intake of fish and poultry; low intake of dairy products, and red meat; and wine in moderation, consumed with meals ${ }^{88)}$. This traditional dietary pattern was shown to be associated with reduced risk of CVD in the Seven Countries Study in 1950s ${ }^{89)}$, and in more recent studies ${ }^{87,90)}$. A meta-analysis (2011) of 10 RCTs reported that adherence to the MedDiet was associated with reduced BP: $-2.4 \mathrm{mmHg}(95 \% \mathrm{CI}-3.5$ to $-1.2)$ for SBP and $-1.6 \mathrm{mmHg}(-2.0 \text { to }-1.1)^{91)}$. MedDiet and DASH have in common greater intakes of fruit, vegetables, nuts and fish and low intake of meat, with the MedDiet including more olive oil but fewer dairy products compared to the DASH diet. The 2010 Dietary Guidelines Advisory Committee reviewed articles published between 2009 and 2010 concluded that moderate amounts of low-fat or reduced-fat dairy products improved BP and decreased HTN risk ${ }^{22)}$.

The guidelines of lifestyle modifications for management and prevention of HTN (2014, by ASH and the $\mathrm{ISH})^{93)}$ remained unchanged compared to the 1995 guidelines: ${ }^{22)}$ healthy weight, salt reduction, moderate alcohol consumption, regular aerobic exercise and quit smoking. Most of the guidelines do recommend a healthy eating pattern: mainly plant-based foods such as fruits, vegetables, wholegrain foods; moderate amounts of low-fat or reduced-fat dairy products, moderate amounts of lean unprocessed meats, poultry and fish, moderate amounts of PUFA and MUFA (e.g. olive oil), and reduce amounts of SFA and cholesterol ${ }^{1,2,11-14,83)}$. Persons with HTN are also advised to increase the intake of fish in a few guidelines ${ }^{13,14}$. Although the DASH-Na diet is often 
recommended as part of the guidelines for management and prevention of HTN, it is not endorsed by many Asian countries, such as China, where populations consume fewer dairy products than in Western countries.

The 2002 China National Nutrition and Health Survey reported that a higher traditional southern pattern score (a diet characterized by high intakes of fruit, pork, poultry, rice, vegetables, fish and seafood, and nuts) was associated with a lower prevalence of HTN, independent of BMI ( $P$ for trend=0.01); odds ratio for the top vs bottom quartile of traditional southern pattern diet score was 0.8 (95\% CI, 0.6-0.9) ${ }^{94)}$. This southern Chinese diet has a similar combination of foods as the DASH diet, except dairy products. A pilot study, DASH for Koreans (K-DASH), developed culturally sensitive dietary guidelines by the adaptation of DASH-Na diet and demonstrated the efficacy of this $\mathrm{K}-\mathrm{DASH}$ intervention in reducing $\mathrm{HBP}$ in Korean Americans ${ }^{95)}$. The country-specific foods and beverages from the dietary recalls in the INTERMAP Study may provide information for developing culturally tailored dietary guidelines for management and prevention of HTN.

In summary, the INTERMAP findings on nutrients and foods associated with BP levels of individuals from four countries support current recommendations for a diet high in fruit and vegetables, whole grains, nuts and legumes, fish, lean meats, and poultry as well as low-fat dairy products, and low in $\mathrm{Na}$ and SFA, as part of comprehensive nutritional/lifestyle approaches to preventing and controlling major established cardiovascular risk factors and epidemic CVD.

\section{Acknowledgements}

The study is supported by grants R01 HL50490 and R01 HL084228 from the National Heart, Lung, and Blood Institute, National Institutes of Health (Bethesda, Maryland, USA); by national agencies in PRC, Japan, and the UK. The sponsors had no role in the design or conduct of the study; the collection, management, analysis, or interpretation of the data; or the preparation, review, or approval of the manuscript. We thank all INTERMAP staff for their invaluable efforts; a partial listing of these colleagues is given in Reference 26 of this paper.

\section{Conflicts of Interest}

Paul Elliott is supported in part by the National Institute for Health Research (NIHR) Biomedical Research Centre, Imperial College Healthcare NHS
Trust and Imperial College London.

\section{References}

1) Chobanian AV, Bakris GL, Black HR, Cushman WC, Green LA, Izzo JL, Jr., Jones DW, Materson BJ, Oparil S, Wright JT, Jr., Roccella EJ, and the National High Blood Pressure Education Program Coordinating Committee: The seventh report of the joint national committee on prevention, detection, evaluation, and treatment of high blood pressure: The JNC 7 report. JAMA, 2003; 289: 2560-2572

2) Hypertebsion: clinical management of primary hypertension in adults. CG127. London: National Institute for Health and Care Excellence August 20112011

3) Van den Hoogen PC, Feskens EJ, Nagelkerke NJ, Menotti A, Nissinen A, Kromhout D: The relation between blood pressure and mortality due to coronary heart disease among men in different parts of the world. Seven countries study research group. The New England journal of medicine, 2000; 342: 1-8

4) Ezzati M, Lopez AD, Rodgers A, Vander Hoorn S, Murray CJ, Comparative Risk Assessment Collaborating Group: Selected major risk factors and global and regional burden of disease. Lancet, 2002; 360: 1347-1360

5) Murray CJ, Richards MA, Newton JN, Fenton KA, Anderson HR, Atkinson C, Bennett D, Bernabe E, Blencowe H, Bourne R, Braithwaite T, Brayne C, Bruce NG, Brugha TS, Burney P, Dherani M, Dolk H, Edmond K, Ezzati M, Flaxman AD, Fleming TD, Freedman G, Gunnell D, Hay RJ, Hutchings SJ, Ohno SL, Lozano R, Lyons RA, Marcenes W, Naghavi M, Newton CR, Pearce N, Pope D, Rushton L, Salomon JA, Shibuya K, Vos T, Wang H, Williams HC, Woolf AD, Lopez AD, Davis A: UK health performance: Findings of the global burden of disease study 2010. Lancet, 2013; 381: 997-1020

6) Lim SS, Vos T, Flaxman AD, Danaei G, Shibuya K, Adair-Rohani H, Amann M, Anderson HR, Andrews KG, Aryee M, Atkinson C, Bacchus LJ, Bahalim AN, Balakrishnan K, Balmes J, Barker-Collo S, Baxter A, Bell ML, Blore JD, Blyth F, Bonner C, Borges G, Bourne R, Boussinesq $M$, Brauer $M$, Brooks P, Bruce NG, Brunekreef B, Bryan-Hancock C, Bucello C, Buchbinder R, Bull F, Burnett RT, Byers TE, Calabria B, Carapetis J, Carnahan E, Chafe Z, Charlson F, Chen H, Chen JS, Cheng AT, Child JC, Cohen A, Colson KE, Cowie BC, Darby S, Darling S, Davis A, Degenhardt L, Dentener F, Des Jarlais DC, Devries K, Dherani M, Ding EL, Dorsey ER, Driscoll T, Edmond K, Ali SE, Engell RE, Erwin PJ, Fahimi S, Falder G, Farzadfar F, Ferrari A, Finucane MM, Flaxman S, Fowkes FG, Freedman G, Freeman MK, Gakidou E, Ghosh S, Giovannucci E, Gmel G, Graham K, Grainger R, Grant B, Gunnell D, Gutierrez HR, Hall W, Hoek HW, Hogan A, Hosgood HD, 3rd, Hoy D, Hu H, Hubbell BJ, Hutchings SJ, Ibeanusi SE, Jacklyn GL, Jasrasaria R, Jonas JB, Kan H, Kanis JA, Kassebaum N, Kawakami N, Khang YH, Khatibzadeh S, Khoo JP, Kok C, Laden F, Lalloo R, Lan Q, Lathlean T, Leasher JL, Leigh J, Li Y, Lin JK, Lipshultz SE, London S, Lozano R, 
Lu Y, Mak J, Malekzadeh R, Mallinger L, Marcenes W, March L, Marks R, Martin R, McGale P, McGrath J, Mehta S, Mensah GA, Merriman TR, Micha R, Michaud C, Mishra V, Mohd Hanafiah K, Mokdad AA, Morawska L, Mozaffarian D, Murphy T, Naghavi M, Neal B, Nelson PK, Nolla JM, Norman R, Olives C, Omer SB, Orchard J, Osborne R, Ostro B, Page A, Pandey KD, Parry CD, Passmore E, Patra J, Pearce N, Pelizzari PM, Petzold M, Phillips MR, Pope D, Pope CA, 3rd, Powles J, Rao M, Razavi H, Rehfuess EA, Rehm JT, Ritz B, Rivara FP, Roberts T, Robinson C, Rodriguez-Portales JA, Romieu I, Room R, Rosenfeld LC, Roy A, Rushton L, Salomon JA, Sampson U, Sanchez-Riera L, Sanman E, Sapkota A, Seedat S, Shi P, Shield K, Shivakoti R, Singh GM, Sleet DA, Smith E, Smith KR, Stapelberg NJ, Steenland K, Stockl H, Stovner LJ, Straif K, Straney L, Thurston GD, Tran JH, Van Dingenen R, van Donkelaar A, Veerman JL, Vijayakumar L, Weintraub R, Weissman MM, White RA, Whiteford H, Wiersma ST, Wilkinson JD, Williams HC, Williams W, Wilson N, Woolf AD, Yip P, Zielinski JM, Lopez AD, Murray CJ, Ezzati M, AlMazroa MA, Memish ZA: A comparative risk assessment of burden of disease and injury attributable to 67 risk factors and risk factor clusters in 21 regions, 1990-2010: A systematic analysis for the global burden of disease study 2010. Lancet, 2012; 380: 2224-2260

7) Kearney PM, Whelton M, Reynolds K, Muntner P, Whelton PK, He J: Global burden of hypertension: Analysis of worldwide data. Lancet, 2005; 365: 217-223

8) Miura K, Nagai M, Ohkubo T: Epidemiology of hypertension in Japan: Where are we now? Circ J, 2013; 77: 2226-2231

9) Gillespie CD, Hurvitz KA, Centers for Disease C, Prevention: Prevalence of hypertension and controlled hypertension-united states, 2007-2010. MMWR Surveill Summ, 2013; 62 Suppl 3: 144-148

10) Van den Berg N, Meinke-Franze C, Fiss T, Baumeister SE, Hoffmann W: Prevalence and determinants of controlled hypertension in a German population cohort. BMC Public Health, 2013; 13: 594

11) Australia National Heart Foundation. Guide to management of hypertension 2008

12) Blacher J, Halimi JM, Hanon O, Mourad JJ, Pathak A, Schnebert B, Girerd X, French Society of Hypertension: Management of hypertension in adults: The 2013 French Society of Hypertension guidelines. Fundam Clin Pharmacol, 2014; 28: 1-9

13) Mancia G, Fagard R, Narkiewicz K, Redon J, Zanchetti A, Bohm M, Christiaens T, Cifkova R, De Backer G, Dominiczak A, Galderisi M, Grobbee DE, Jaarsma T, Kirchhof P, Kjeldsen SE, Laurent S, Manolis AJ, Nilsson PM, Ruilope LM, Schmieder RE, Sirnes PA, Sleight P, Viigimaa M, Waeber B, Zannad F, Redon J, Dominiczak A, Narkiewicz K, Nilsson PM, Burnier M, Viigimaa M, Ambrosioni E, Caufield M, Coca A, Olsen MH, Schmieder RE, Tsioufis C, van de Borne P, Zamorano JL, Achenbach S, Baumgartner H, Bax JJ, Bueno H, Dean V, Deaton C, Erol C, Fagard R, Ferrari R, Hasdai D, Hoes AW, Kirchhof P, Knuuti J, Kolh P, Lancellotti P, Linhart A, Nihoyannopoulos P, Piepoli MF, Ponikowski P, Sirnes PA,
Tamargo JL, Tendera M, Torbicki A, Wijns W, Windecker S, Clement DL, Coca A, Gillebert TC, Tendera M, Rosei EA, Ambrosioni E, Anker SD, Bauersachs J, Hitij JB, Caulfield M, De Buyzere M, De Geest S, Derumeaux GA, Erdine S, Farsang C, Funck-Brentano C, Gerc V, Germano G, Gielen S, Haller H, Hoes AW, Jordan J, Kahan T, Komajda M, Lovic D, Mahrholdt H, Olsen MH, Ostergren J, Parati G, Perk J, Polonia J, Popescu BA, Reiner Z, Ryden L, Sirenko Y, Stanton A, StruijkerBoudier H, Tsioufis C, van de Borne P, Vlachopoulos C, Volpe M, Wood DA: 2013 ESH/ESC guidelines for the management of arterial hypertension: The Task Force for the Management of Arterial Hypertension of the European Society of Hypertension (ESH) and of the European Society of Cardiology (ESC). Eur Heart J, 2013; 34: 2159-2219

14) Shimamoto K, Ando K, Fujita T, Hasebe N, Higaki J, Horiuchi M, Imai Y, Imaizumi T, Ishimitsu T, Ito M, Ito $S$, Itoh $\mathrm{H}$, Iwao $\mathrm{H}$, Kai $\mathrm{H}$, Kario $\mathrm{K}$, Kashihara $\mathrm{N}$, Kawano Y, Kim-Mitsuyama S, Kimura G, Kohara K, Komuro I, Kumagai H, Matsuura H, Miura K, Morishita R, Naruse M, Node K, Ohya Y, Rakugi H, Saito I, Saitoh S, Shimada K, Shimosawa T, Suzuki H, Tamura K, Tanahashi N, Tsuchihashi T, Uchiyama M, Ueda S, Umemura S, Japanese Society of Hypertension Committee for Guidelines for the Management of Hypertension: The Japanese Society of Hypertension Guidelines for the Management of Hypertension (JSH 2014). Hypertens Res, 2014; 37: 253-390

15) Eckel RH, Jakicic JM, Ard JD, de Jesus JM, Houston Miller N, Hubbard VS, Lee IM, Lichtenstein AH, Loria CM, Millen BE, Nonas CA, Sacks FM, Smith SC, Jr., Svetkey LP, Wadden TA, Yanovski SZ, American College of Cardiology/American Heart Association Task Force on Practice Group: 013 AHA/ACC guideline on lifestyle management to reduce cardiovascular risk: a report of the American College of Cardiology/American Heart Association Task Force on Practice Guidelines. J Am Coll Cardiol, 2014; 63: 2960-2984

16) James PA, Oparil S, Carter BL, Cushman WC, DennisonHimmelfarb C, Handler J, Lackland DT, LeFevre ML, MacKenzie TD, Ogedegbe O, Smith SC, Jr., Svetkey LP, Taler SJ, Townsend RR, Wright JT, Jr., Narva AS, Ortiz E: 2014 evidence-based guideline for the management of high blood pressure in adults: report from the panel members appointed to the Eighth Joint National Committee (JNC 8). JAMA, 2014; 311: 507-520

17) Appel LJ, Moore TJ, Obarzanek E, Vollmer WM, Svetkey LP, Sacks FM, Bray GA, Vogt TM, Cutler JA, Windhauser MM, Lin PH, Karanja N: A clinical trial of the effects of dietary patterns on blood pressure. Dash Collaborative Research Group. N Engl J Med, 1997; 336: $1117-1124$

18) The INTERSALT co-operative research group: Sodium, potassium, body mass, alcohol and blood pressure: The INTERSALT Study. J Hypertens Suppl, 1988; 6: S584586

19) The INTERSALT co-operative research group: INTERSALT: An international study of electrolyte excretion and blood pressure. Results for 24 hour urinary sodium and 
potassium excretion. BMJ, 1988; 297: 319-328

20) Dyer AR, Elliott P: The INTERSALT Study: Relations of body mass index to blood pressure. Intersalt co-operative research group. J.Hum.Hypertens, 1989; 3: 299-308

21) Marmot MG, Elliott P, Shipley MJ, Dyer AR, Ueshima H, Beevers DG, Stamler R, Kesteloot H, Rose G, Stamler $\mathrm{J}$ : Alcohol and blood pressure: The INTERSALT Study. BMJ, 1994; 308: 1263-1267

22) The sixth report of the joint national committee on prevention, detection, evaluation, and treatment of high blood pressure. Arch Intern Med, 1997; 157: 2413-2446

23) Cutler JA, Follmann D, Allender PS: Randomized trials of sodium reduction: An overview. Am J Clin Nutr, 1997; 65: 643S-651S

24) Stamler J, Caggiula AW, Grandits GA: Relation of body mass and alcohol, nutrient, fiber, and caffeine intakes to blood pressure in the special intervention and usual care groups in the multiple risk factor intervention trial. Am J Clin Nutr, 1997; 65: 338S-365S

25) Midgley JP, Matthew AG, Greenwood CM, Logan AG: Effect of reduced dietary sodium on blood pressure: A meta-analysis of randomized controlled trials. JAMA, 1996; 275: 1590-1597

26) Stamler J, Elliott P, Dennis B, Dyer AR, Kesteloot H, Liu $\mathrm{K}$, Ueshima H, Zhou BF for the INTERMAP Research Group: INTERMAP: Background, aims, design, methods, and descriptive statistics (nondietary). J Hum Hypertens, 2003; 17: 591-608

27) Dennis B, Stamler J, Buzzard M, Conway R, Elliott P, Moag-Stahlberg A, Okayama A, Okuda N, Robertson C, Robinson F, Schakel S, Stevens M, Van HN, Zhao L, Zhou BF: INTERMAP: The dietary data--process and quality control. J Hum Hypertens, 2003; 17: 609-622

28) Kaspar H, Dettmer K, Chan Q, Daniels S, Nimkar S, Daviglus ML, Stamler J, Elliott P, Oefner PJ: Urinary amino acid analysis: A comparison of iTRAQ (R)-LCMS/MS, GC-MS, and amino acid analyzer. Journal of Chromatography B-Analytical Technologies in the Biomedical and Life Sciences, 2009; 877: 1838-1846

29) Holmes E, Loo RL, Stamler J, Bictash M, Yap IKS, Chan Q, Ebbels T, De Iorio M, Brown IJ, Veselkov KA, Daviglus ML, Kesteloot H, Ueshima H, Zhao L, Nicholson JK, Elliott P: Human metabolic phenotype diversity and its association with diet and blood pressure. Nature, 2008; 453: 396-U350

30) Elliott P, Stamler J, Dyer AR, Appel L, Dennis B, Kesteloot H, Ueshima H, Okayama A, Chan Q, Garside DB, Zhou B: Association between protein intake and blood pressure: The INTERMAP study. Arch Intern Med, 2006; 166: 79-87

31) Stamler J, Brown IJ, Daviglus ML, Chan Q, Kesteloot H, Ueshima H, Zhao L, Elliott P for the INTERMAP Research Group: Glutamic acid, the main dietary amino acid, and blood pressure: The INTERMAP study (international collaborative study of macronutrients, micronutrients and blood pressure). Circulation, 2009; 120: 221228

32) Aljuraiban GS, Griep LM, Chan Q, Daviglus ML, Stamler J, Van Horn L, Elliott P, Frost GS: Total, insoluble and soluble dietary fibre intake in relation to blood pressure:
The intermap study. Br J Nutr, 2015: 1-7

33) Miura K, Stamler J, Nakagawa H, Elliott P, Ueshima $H$, Chan Q, Brown IJ, Tzoulaki I, Saitoh S, Dyer AR, Daviglus ML, Kesteloot H, Okayama A, Curb JD, Rodriguez BL, Elmer PJ, Steffen LM, Robertson C, Zhao L, Elliott P for the INTERMAP Research Group: Relationship of dietary linoleic acid to blood pressure - the international study of macro-micronutrients and blood pressure study. Hypertension, 2008; 52: 408-414

34) Miura K, Stamler J, Brown IJ, Ueshima H, Nakagawa H, Sakurai M, Chan Q, Appel LJ, Okayama A, Okuda N, Curb JD, Rodriguez BL, Robertson C, Zhao L, Elliott P for the INTERMAP Research Group: Relationship of dietary monounsaturated fatty acids to blood pressure: The international study of macro/micronutrients and blood pressure. J Hypertens, 2013; 31: 1144-1150

35) Ueshima H, Stamler J, Elliott P, Chan Q, Brown IJ, Carnethon MR, Daviglus ML, He K, Moag-Stahlberg A, Rodriguez BL, Steffen LM, Van Horn L, Yarnell J, Zhou B: Food omega-3 fatty acid intake of individuals (total, linolenic acid, long-chain) and their blood pressure INTERMAP study. Hypertension, 2007; 50: 313-319

36) Elliott P, Kesteloot H, Appel LJ, Dyer AR, Ueshima H, Chan Q, Brown IJ, Zhao L, Stamler J for the INTERMAP Research Group: Dietary phosphorus and blood pressure: International study of macro- and micro-nutrients and blood pressure. Hypertension, 2008; 51: 669675

37) Tzoulaki I, Brown IJ, Chan Q, Van Horn L, Ueshima H, Zhao L, Stamler J, Elliott P for the International Collaborative Research Group on Macro-/Micronutrients and Blood Pressure: Relation of iron and red meat intake to blood pressure: Cross sectional epidemiological study. BMJ, 2008; 337

38) Brown IJ, Elliott P, Robertson CE, Chan Q, Daviglus ML, Dyer AR, Huang CC, Rodriguez BL, Sakata K, Ueshima H, Van HL, Zhao L, Stamler J: Dietary starch intake of individuals and their blood pressure: The international study of macronutrients and micronutrients and blood pressure. J.Hypertens, 2009; 27: 231-236

39) Brown IJ, Stamler J, Van Horn L, Robertson CE, Chan Q, Dyer AR, Huang CC, Rodriguez BL, Zhao L, Daviglus ML, Ueshima H, Elliott P, International Study of Macro/Micronutrients, Blood Pressure Research Group: Sugar-sweetened beverage, sugar intake of individuals, and their blood pressure: International Study of Macro/ Micronutrients and Blood Pressure Research Group. Hypertension, 2011; 57: 695-701

40) Sakurai M, Stamler J, Miura K, Brown IJ, Nakagawa H, Elliott P, Ueshima H, Chan Q, Tzoulaki I, Dyer AR, Okayama A, Zhao L for the INTERMAP Research Group: Relationship of dietary cholesterol to blood pressure: The INTERMAP study. J Hypertens, 2011; 29: 222-228

41) Stamler J, Brown IJ, Daviglus ML, Chan Q, Miura K, Okuda N, Ueshima H, Zhao L, Elliott P: Dietary glycine and blood pressure: The international study on macro/ micronutrients and blood pressure. Am J Clin Nutr, 2013; 98: 136-145

42) Liu L, Ikeda K, Sullivan DH, Ling W, Yamori Y: Epide- 
miological evidence of the association between dietary protein intake and blood pressure: A meta-analysis of published data. Hypertension Res, 2002; 25: 689-695

43) Altorf-van der Kuil W, Engberink MF, Brink EJ, van Baak MA, Bakker SJ, Navis G, van't Veer P, Geleijnse JM: Dietary protein and blood pressure: A systematic review. PloS one, 2010; 5: e12102

44) Rebholz CM, Friedman EE, Powers LJ, Arroyave WD, He J, Kelly TN: Dietary protein intake and blood pressure: A meta-analysis of randomized controlled trials. Am J Epidemiol, 2012; 176 Suppl 7: S27-S43

45) Tielemans SM, Altorf-van der Kuil W, Engberink MF, Brink EJ, van Baak MA, Bakker SJ, Geleijnse JM: Intake of total protein, plant protein and animal protein in relation to blood pressure: A meta-analysis of observational and intervention studies. J Hum Hypertens, 2013; 27: 564-571

46) Appel LJ, Miller ER, 3rd, Seidler AJ, Whelton PK: Does supplementation of diet with 'fish oil' reduce blood pressure? A meta-analysis of controlled clinical trials. Arch Intern Med, 1993; 153: 1429-1438

47) Geleijnse JM, Giltay EJ, Grobbee DE, Donders AR, Kok FJ: Blood pressure response to fish oil supplementation: Metaregression analysis of randomized trials. J Hypertens, 2002; 20: 1493-1499

48) Wendland E, Farmer A, Glasziou P, Neil A: Effect of alpha linolenic acid on cardiovascular risk markers: A systematic review. Heart, 2006; 92: 166-169

49) Alonso A, Ruiz-Gutierrez V, Martinez-Gonzalez MA: Monounsaturated fatty acids, olive oil and blood pressure: Epidemiological, clinical and experimental evidence. Public Health Nutr, 2006; 9: 251-257

50) Nicklas TA, Hampl JS, Taylor CA, Thompson VJ, Heird WC: Monounsaturated fatty acid intake by children and adults: Temporal trends and demographic differences. Nutr Rev, 2004; 62: 132-141

51) Schwingshackl L, Strasser B, Hoffmann G: Effects of monounsaturated fatty acids on cardiovascular risk factors: A systematic review and meta-analysis. Ann Nutr Metab, 2011; 59: 176-186

52) Schwab U, Lauritzen L, Tholstrup T, Haldorssoni T, Riserus $\mathrm{U}$, Uusitupa M, Becker W: Effect of the amount and type of dietary fat on cardiometabolic risk factors and risk of developing type 2 diabetes, cardiovascular diseases, and cancer: A systematic review. Food Nutr Res, 2014; 58

53) Stamler J, Caggiula A, Grandits GA, Kjelsberg M, Cutler JA: Relationship to blood pressure of combinations of dietary macronutrients. Findings of the Multiple Risk Factor Intervention Trial (MRFIT). Circulation, 1996; 94: 2417-2423

54) Shah M, Adams-Huet B, Garg A: Effect of high-carbohydrate or high-cis-monounsaturated fat diets on blood pressure: A meta-analysis of intervention trials. Am J Clin Nutr, 2007; 85: 1251-1256

55) Ha V, Sievenpiper JL, de Souza RJ, Chiavaroli L, Wang DD, Cozma AI, Mirrahimi A, Yu ME, Carleton AJ, Dibuono M, Jenkins AL, Leiter LA, Wolever TM, Beyene J, Kendall CW, Jenkins DJ: Effect of fructose on blood pressure: A systematic review and meta-analysis of controlled feeding trials. Hypertension, 2012; 59: 787-795
56) Kelishadi R, Mansourian M, Heidari-Beni M: Association of fructose consumption and components of metabolic syndrome in human studies: A systematic review and meta-analysis. Nutrition, 2014; 30: 503-510

57) Te Morenga LA, Howatson AJ, Jones RM, Mann J: Dietary sugars and cardiometabolic risk: Systematic review and meta-analyses of randomized controlled trials of the effects on blood pressure and lipids. Am J Clin Nutr, 2014; 100: 65-79

58) Whelton SP, Hyre AD, Pedersen B, Yi Y, Whelton PK, He $\mathrm{J}$ : Effect of dietary fiber intake on blood pressure: A metaanalysis of randomized, controlled clinical trials. J Hypertens, 2005; 23: 475-481

59) Streppel MT, Arends LR, van 't Veer P, Grobbee DE, Geleijnse JM: Dietary fiber and blood pressure: A metaanalysis of randomized placebo-controlled trials. Arch Intern Med, 2005; 165: 150-156

60) Evans CE, Greenwood DC, Threapleton DE, Cleghorn CL, Nykjaer C, Woodhead CE, Gale CP, Burley VJ: Effects of dietary fibre type on blood pressure: A systematic review and meta-analysis of randomized controlled trials of healthy individuals. J Hypertens, 2015; 33: $897-$ 911

61) Alonso A, Nettleton JA, Ix JH, de Boer IH, Folsom AR, Bidulescu A, Kestenbaum BR, Chambless LE, Jacobs DR, Jr: Dietary phosphorus, blood pressure, and incidence of hypertension in the atherosclerosis risk in communities study and the multi-ethnic study of atherosclerosis. Hypertension, 2010; 55: 776-784

62) Allender PS, Cutler JA, Follmann D, Cappuccio FP, Pryer J, Elliott P: Dietary calcium and blood pressure: A metaanalysis of randomized clinical trials. Ann Intern Med, 1996; 124: 825-831

63) Griffith LE, Guyatt GH, Cook RJ, Bucher HC, Cook DJ: The influence of dietary and nondietary calcium supplementation on blood pressure: An updated metaanalysis of randomized controlled trials. Am J Hypertens, 1999; 12: 84-92

64) van Mierlo LA, Arends LR, Streppel MT, Zeegers MP, Kok FJ, Grobbee DE, Geleijnse JM: Blood pressure response to calcium supplementation: A meta-analysis of randomized controlled trials. J Hum Hypertens, 2006; 20: $571-580$

65) Dickinson HO, Nicolson DJ, Cook JV, Campbell F, Beyer FR, Ford GA, Mason J: Calcium supplementation for the management of primary hypertension in adults. Cochrane Database Syst Rev, 2006; CD004639

66) Mizushima S, Cappuccio FP, Nichols R, Elliott P: Dietary magnesium intake and blood pressure: A qualitative overview of the observational studies. J Hum Hypertens, 1998; 12: 447-453

67) Jee SH, Miller ER, 3rd, Guallar E, Singh VK, Appel LJ, Klag MJ: The effect of magnesium supplementation on blood pressure: A meta-analysis of randomized clinical trials. Am J Hypertens, 2002; 15: 691-696

68) Dickinson HO, Nicolson DJ, Campbell F, Cook JV, Beyer FR, Ford GA, Mason J: Magnesium supplementation for the management of essential hypertension in adults. Cochrane Database Syst Rev, 2006; CD004640

69) Dai Q, Shu XO, Deng X, Xiang YB, Li H, Yang G, 
Shrubsole MJ, Ji B, Cai H, Chow WH, Gao YT, Zheng W: Modifying effect of calcium/magnesium intake ratio and mortality: A population-based cohort study. BMJ open, 2013; 3

70) Galan P, Vergnaud AC, Tzoulaki I, Buyck JF, Blacher J, Czernichow S, Hercberg S: Low total and nonheme iron intakes are associated with a greater risk of hypertension. J Nutr, 2010; 140: 75-80

71) Munoz-Bravo C, Gutierrez-Bedmar M, Gomez-Aracena J, Garcia-Rodriguez A, Navajas JF: Iron: Protector or risk factor for cardiovascular disease? Still controversial. Nutrients, 2013; 5: 2384-2404

72) Fang X, An P, Wang H, Wang X, Shen X, Li X, Min J, Liu S, Wang F: Dietary intake of heme iron and risk of cardiovascular disease: A dose-response meta-analysis of prospective cohort studies. Nutr Metab Cardiovasc Dis, 2015; 25: 24-35

73) Stamler J, Brown IJ, Elliott P, Daviglus ML, Dyer AR, Garside DB, Van HL, Appel LJ, Chan Q, Tzoulaki I, Kesteloot H, Miura K, Okuda N, Ueshima H, Zhao LC: Improved nutrition: Key to solving the populationwide blood pressure problem. In: Mancini M, Ordovas J, Riccardi G, Rubba P, Strazzullo P, eds. Nutritional and metabolic bases of cardiovascular disease. Oxford, UK.: WileyBlackwell, 2011; 303-324

74) Tzoulaki I, Patel CJ, Okamura T, Chan Q, Brown IJ, Miura K, Ueshima H, Zhao L, Van Horn L, Daviglus ML, Stamler J, Butte AJ, Ioannidis JP, Elliott P: A nutrient-wide association study on blood pressure. Circulation, 2012; 126: 2456-2464

75) Svetkey LP, Sacks FM, Obarzanek E, Vollmer WM, Appel LJ, Lin PH, Karanja NM, Harsha DW, Bray GA, Aickin M, Proschan MA, Windhauser MM, Swain JF, McCarron PB, Rhodes DG, Laws RL: The DASH diet, sodium intake and blood pressure trial (DASH-sodium): Rationale and design. DASH-sodium collaborative research group. J Am Diet Assoc, 1999; 99: S96-104

76) Appel LJ, Sacks FM, Carey VJ, Obarzanek E, Swain JF, Miller ER, III, Conlin PR, Erlinger TP, Rosner BA, Laranjo NM, Charleston J, McCarron P, Bishop LM: Effects of protein, monounsaturated fat, and carbohydrate intake on blood pressure and serum lipids: Results of the omniheart randomized trial. JAMA, 2005; 294: 24552464

77) Molitor J, Brown IJ, Chan Q, Papathomas M, Liverani S, Molitor N, Richardson S, Van Horn L, Daviglus ML, Dyer A, Stamler J, Elliott P for the INTERMAP Research Group: Blood pressure differences associated with Optimal Macronutrient Intake Trial for Heart Health (OMNIHEART)-like diet compared with a typical American Diet. Hypertension, 2014; 64: 1198-1204

78) Chan Q, Stamler J, Brown IJ, Daviglus ML, Van Horn L, Dyer AR, Oude Griep LM, Miura K, Ueshima H, Zhao L, Nicholson JK, Holmes E, Elliott P for the INTERMAP Research Group: Relation of raw and cooked vegetable consumption to blood pressure: The INTERMAP study. J Hum Hypertens, 2014; 28: 353-359

79) Oude Griep LM, Stamler J, Chan Q, Van Horn L, Steffen LM, Miura K, Ueshima H, Okuda N, Zhao L, Daviglus ML, Elliott P for the INTERMAP Research Group: Asso- ciation of raw fruit and fruit juice consumption with blood pressure: The INTERMAP study. Am J Clin Nutr, 2013; 97: 1083-1091

80) He FJ, MacGregor GA: Salt and sugar: Their effects on blood pressure. Pflugers Arch, 2015; 467: 577-586

81) Singh GM, Micha R, Khatibzadeh S, Lim S, Ezzati M, Mozaffarian D, Global Burden of Diseases Nutrition and Chronic Diseases Expert Group (NutriCoDE): Estimated global, regional, and national disease burdens related to sugar-sweetened beverage consumption in 2010. Circulation, 2015; 132: 639-666

82) Khan NA, Hemmelgarn B, Herman RJ, Bell CM, Mahon JL, Leiter LA, Rabkin SW, Hill MD, Padwal R, Touyz RM, Larochelle P, Feldman RD, Schiffrin EL, Campbell NR, Moe G, Prasad R, Arnold MO, Campbell TS, Milot A, Stone JA, Jones C, Ogilvie RI, Hamet P, Fodor G, Carruthers G, Burns KD, Ruzicka M, DeChamplain J, Pylypchuk G, Petrella R, Boulanger JM, Trudeau L, Hegele RA, Woo V, McFarlane P, Vallee M, Howlett J, Bacon SL, Lindsay P, Gilbert RE, Lewanczuk RZ, Tobe S, Canadian Hypertension Education Program: The 2009 canadian hypertension education program recommendations for the management of hypertension: Part 2--therapy. Can J Cardiol, 2009; 25: 287-298

83) Gupta R, Guptha S: Strategies for initial management of hypertension. Indian J Med Res, 2010; 132: 531-542

84) Fung TT, Hu FB, Wu K, Chiuve SE, Fuchs CS, Giovannucci E: The mediterranean and dietary approaches to stop hypertension (DASH) diets and colorectal cancer. Am J Clin Nutr, 2010; 92: 1429-1435

85) Fung TT, Hu FB, Hankinson SE, Willett WC, Holmes MD: Low-carbohydrate diets, dietary approaches to stop hypertension-style diets, and the risk of postmenopausal breast cancer. Am J Epidemiol, 2011; 174: 652-660

86) de Koning L, Chiuve SE, Fung TT, Willett WC, Rimm $\mathrm{EB}, \mathrm{Hu} \mathrm{FB}$ : Diet-quality scores and the risk of type 2 diabetes in men. Diabetes care, 2011; 34: 1150-1156

87) Estruch R, Ros E, Salas-Salvado J, Covas MI, Corella D, Aros F, Gomez-Gracia E, Ruiz-Gutierrez V, Fiol M, Lapetra J, Lamuela-Raventos RM, Serra-Majem L, Pinto X, Basora J, Munoz MA, Sorli JV, Martinez JA, MartinezGonzalez MA: Primary prevention of cardiovascular disease with a mediterranean diet. N Engl J Med, 2013; 368: 1279-1290

88) Willett WC, Sacks F, Trichopoulou A, Drescher G, FerroLuzzi A, Helsing E, Trichopoulos D: Mediterranean diet pyramid: A cultural model for healthy eating. Am J Clin Nutr, 1995; 61: 1402S-1406S

89) Keys A: Coronary heart disease--the global picture. Atherosclerosis, 1975; 22: 149-192

90) Martinez-Gonzalez MA, Bes-Rastrollo M, Serra-Majem L, Lairon D, Estruch R, Trichopoulou A: Mediterranean food pattern and the primary prevention of chronic disease: Recent developments. Nutr Rev, 2009; 67 Suppl 1: S111-116

91) Kastorini CM, Milionis HJ, Esposito K, Giugliano D, Goudevenos JA, Panagiotakos DB: The effect of mediterranean diet on metabolic syndrome and its components: A meta-analysis of 50 studies and 534,906 individuals. J Am Coll Cardiol, 2011; 57: 1299-1313 
92) McGrane MM, Essery E, Obbagy J, Lyon J, Macneil P, Spahn J, Van Horn L: Dairy consumption, blood pressure, and risk of hypertension: An evidence-based review of recent literature. Curr Cardiovasc Risk Rep, 2011; 5: 287-298

93) Weber MA, Schiffrin EL, White WB, Mann S, Lindholm LH, Kenerson JG, Flack JM, Carter BL, Materson BJ, Ram CV, Cohen DL, Cadet JC, Jean-Charles RR, Taler S, Kountz D, Townsend RR, Chalmers J, Ramirez AJ, Bakris GL, Wang J, Schutte AE, Bisognano JD, Touyz RM, Sica D, Harrap SB: Clinical practice guidelines for the management of hypertension in the community: A statement by the American Society of Hypertension and the International Society of Hypertension. Clin Hypertens (Greenwich), 2014; 16: 14-26

94) Wang D, He Y, Li Y, Luan D, Yang X, Zhai F, Ma G: Dietary patterns and hypertension among Chinese adults: A nationally representative cross-sectional study. BMC Public Health, 2011; 11: 925

95) Kim H, Song HJ, Han HR, Kim KB, Kim MT: Translation and validation of the dietary approaches to stop hypertension for koreans intervention: Culturally tailored dietary guidelines for Korean Americans with high blood pressure. J Cardiovasc Nurs, 2013; 28: 514-523 